Annals of Warsaw University of Life Sciences - SGGW

Land Reclamation No 42 (1), 2010: 31-37

(Ann. Warsaw Univ. of Life Sci. - SGGW, Land Reclam. 42 (1), 2010)

\title{
Biological assessments of streams that have been adversely impacted by sediment runoff in Idaho, USA
}

\author{
ROBERT L. MAHLER, MICHAEL E. BARBER \\ University of Idaho, Washington State University, USA
}

\begin{abstract}
Biological assessments of streams that have been adversely impacted by sediment runoff in Idaho, USA. Sediments are the major source of pollution in surface waters of the Pacific Northwest Region of the USA. The purpose of this study is to evaluate the relationship between SMI water quality scores at 76 sampling sites in eight watersheds and the observed soil erosion rates on adjacent landscapes. The water quality SMI scores in streams were obtained using stream macro invertebrates as an indicator of water quality, while soil erosion rates were determined by observation on adjoining landscapes during periods of maximum precipitation. Soil erosion rates of $<2,2-5$, $5-15,15-25$ and $>25 \mathrm{mt} / \mathrm{ha} / \mathrm{yr}$ were observed at 9 , $20,45,14$ and $12 \%$ of the sampling sites, respectively. Landscapes with erosion rates of less than $5 \mathrm{mt} / \mathrm{ha} / \mathrm{yr}$ generally resulted in good water quality in adjacent streams; however, when soil erosion rates on adjacent landscapes exceeded $5 \mathrm{mt} / \mathrm{ha} / \mathrm{yr}$ SMI water quality scores were less than good $86 \%$ of the time. Strong significant relationships were observed between SMI water quality rating and observed soil erosion rates. Consequently, land management or rehabilitation practices that reduce soil erosion rates to levels below $5 \mathrm{mt} / \mathrm{ha} /$ /yr should improve stream water quality.
\end{abstract}

Key words: Benthic macro invertebrates, soil erosion, surface water quality, land use, forestry, rangeland, agriculture.

\section{INTRODUCTION}

Biological assessments are a common technique used to evaluate the biological integrity of flowing water bodies. When using a biological assessment inferences can be made about the status or quality of the environment derived from structural and functional attributes of individuals, populations, communities, and ecosystems (Hart 1994). Biological assessments attempt to quantify complex ecological processes into a single score often referred to as an ecological health rating. Biological assessments of water bodies have the two following advantages over more traditional chemical testing of waters: (1) they are less expensive, and (2) they can detect the compound, and even synergistic, effects of pollutants on the environment.

Biological assessments of streams have been developed using algae, bacteria, fish and benthic macro invertebrates. Benthic macro invertebrates are aquatic organisms found in the bottom substratum of water bodies (Plafkin et al. 1989). Benthic macro invertebrates populations are the most commonly used community in biological assessments because of the following distinct attributes: (1) macro invertebrates indicate localized conditions because they are relatively sedentary, (2) macro invertebrates indicate integrated short-term environmental impacts due to their short life cycles, (3) macro invertebrates allow experienced biolo- 
gists (through species identification) to rapidly and easily examine water quality conditions, (4) macro invertebrates possess a wide range of trophic levels and pollution tolerances that allow for comparison, (5) macro invertebrates provide a primary food source for fish, (6) macro invertebrates are relatively easy and economical to sample, and (7) macro invertebrates are abundant and diverse in most streams.

Biological assessments rely on indicators, or metrics, to measure the condition of aquatic communities to perturbations (Barbour et al. 1996). A metric is a characteristic of the biota that changes in some predictable way with increased human influence (Karr 1991). Metrics represent different measurements of the sampled biota, such as total number of taxa, percent abundance of the dominant taxon, percent abundance of intolerant groups, and percent abundance of functional feeding groups (Gerritsen 1995). Ecological indices often incorporate a multimetric approach to reveal the effects of numerous stressors on the structure and function of the aquatic biota. Water body managers prefer multimetric evaluations because they generate a single score that is comparable to a target value generated from reference conditions (Reynoldson et al. 1997).

In Idaho sediments have been determined to account for up to $70 \%$ of the degradation of surface water quality. Research has shown that stream macro invertebrate index (SMI) scores in flowing water bodies are closely related to adjacent land use and management practices (Huels 2002; Tosch 2009). The purpose of this paper is to evaluate the relationship between SMI scores at 726sampling sites in eight watersheds and observed soil erosion rates on adjacent landscapes. The SMI scores were determined over an eight-year period between 2001 and 2008. This paper is a summary of our findings.

\section{MATERIALS AND METHODS}

The biological health of surface water at 76 sampling sites in eight watersheds was determined and expressed using stream macro invertebrate index (SMI) scores (Clark and Maret 1993). The watersheds chosen for this study ranged in size from 9.355 to 82.051 ha and were located throughout the state of Idaho (Tab. 1; Fig. 1). The benthic macro invertebrate sampling took place over an eight-year period and was largely conducted by graduate students at the University of Idaho. The number of actual sampling sites used in a watershed was dependent on adjacent land use and geography and ranged from six to 18. Common land use in the studied watersheds included forestry, agriculture (cropland) and range (livestock grazing).

At each of the 76 sites benthic samples were collected using a modified Hess sampler $\left(0.1 \mathrm{~m}^{2}\right)$ based on the guidelines established by Clark and Maret (1993). The collected samples were washed and sorted in the laboratory to remove organic and inorganic debris. Benthic macro invertebrates were visually sorted from the remaining organic material and set aside for identification. A minimum of 300 macro invertebrates from each collected sample were identified to the genus or species level. The macro invertebrate data were entered into a software package that calculated 97 different metrics 
TABLE 1. The area, land use, year of benthic macro invertebrate sampling, and number of sampling sites in the eight Idaho watersheds evaluated for water quality between 2001 and 2008

\begin{tabular}{|l|c|l|c|c|}
\hline Watershed & Area [ha] & \multicolumn{1}{|c|}{ Land use } & Year sampled & Sampling sites \\
\hline Big Boulder & 82,051 & $\begin{array}{l}95 \% \text { range } \\
5 \% \text { cropland }\end{array}$ & 2003 & 7 \\
\hline Clear & 37,050 & $\begin{array}{l}70 \% \text { forest } \\
25 \% \text { range } \\
5 \% \text { cropland }\end{array}$ & 2008 & 10 \\
\hline Jim Ford & 23,843 & $\begin{array}{l}70 \% \text { forest } \\
15 \% \text { range } \\
15 \% \text { cropland }\end{array}$ & 2001 & 18 \\
\hline Lake & & $\begin{array}{l}60 \% \text { forest } \\
40 \% \text { cropland }\end{array}$ & 2003 & 6 \\
\hline Myrtle & 9,355 & $\begin{array}{l}95 \% \text { forest } \\
5 \% \text { cropland }\end{array}$ & 2004 & 9 \\
\hline Orofino & 10,900 & $\begin{array}{l}86 \% \text { forest } \\
14 \% \text { range }\end{array}$ & 2002 & 8 \\
\hline Paradise & 49,515 & $80 \%$ cropland & 2007 & 10 \\
\hline Silver & 11,055 & $20 \%$ forest & & \\
\hline & 26,772 & $\begin{array}{l}45 \% \text { range } \\
55 \% \text { cropland }\end{array}$ & 2005 & \\
\hline
\end{tabular}
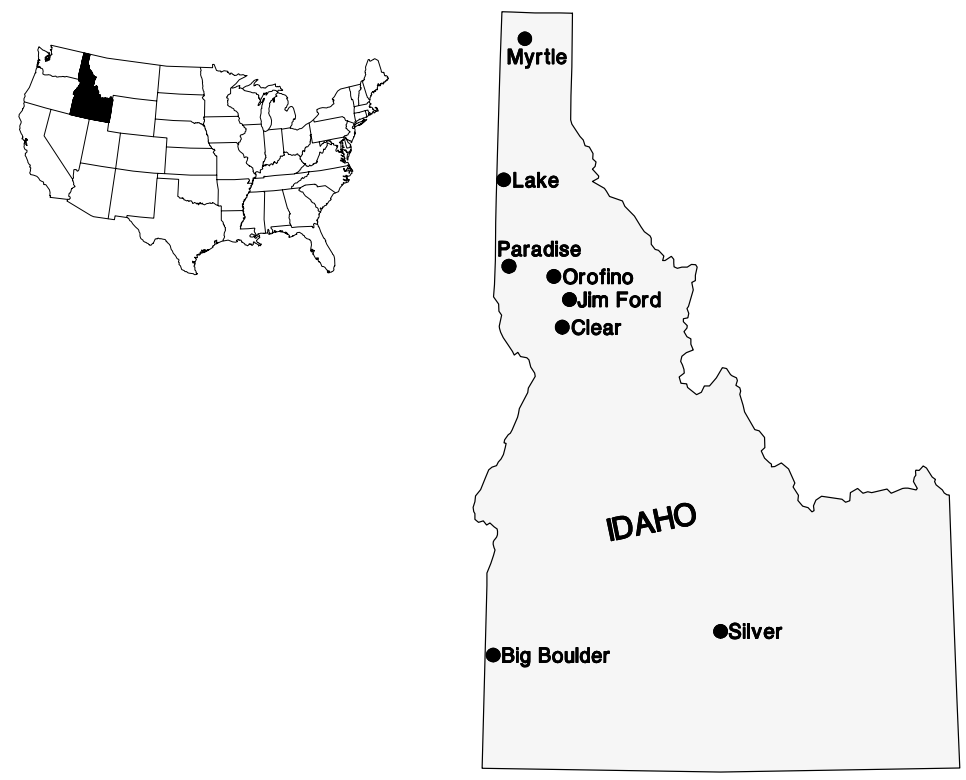

FIGURE 1. Location of the eight watersheds evaluated for water quality using benthic macro invertebrates between 2001 and 2008 in Idaho, USA 
and determined a Stream Macro Invertebrate Index (SMI) score based on state of Idaho protocols. SMI scores of 77 to 100,53 to 76,36 to 52,18 to 35 , and 0 to 18 resulted in ecological heath ratings of very good, good, fair, poor and very poor, respectively.

Erosion rates on lands adjacent to the 76-benthic sampling sites were determined by visual observation in March 2008, June 2008 and again in April 2009. The three observations were averaged to determine the average annual erosion rate. The visual erosion observations were subjective, but approximated soil erosion rates of $<2,2$ to 5,5 to 15,15 to 25 and $>25 \mathrm{mt} / \mathrm{ha} / \mathrm{yr}$. Soil texture at the 76 sampling sites ranged from loamy sands to silty clays; however, sandy loams, silt loams and loams were the most common textural classes observed.

The data were analyzed by relating soil erosion rate to SMI water quality rating and dominant land use to SMI water quality rating. Where appropriate, statistics were used to quantify the relations among land use, erosion rate and surface water quality.

\section{RESULTS AND DISCUSSION}

The SMI scores for water quality at the 76 sampling sites in Idaho ranged from good to very poor (Tab. 2). Approximately 29 , 46,20 and $5 \%$ of the sampling sites were scored with ecological health ratings of good, fair, poor and very poor, respectively. Based on these and other field observations made in Idaho these scores are typical of surface water quality conditions that would be seen in the state. The relatively high concentrations of cropland in the Paradise watershed and logging and grazing activities in the Jim Ford Creek watershed were probably responsible for the lower water quality ratings (Tabs 1 and 2). Conversely, minimal commercial logging activity in the upper part of the Myrtle Creek watershed and significant protected areas in the Silver Creek watershed resulted in higher than average water quality ratings. Within the eight sampled watersheds there is an excellent range (from good to very poor) of water quality conditions.

Soil erosion rates were visually estimated on land adjacent to and land up to

TABLE 2. Water quality rating at sampling sites within the eight Idaho watersheds studied based on metric scores compiled for macro invertebrate evaluations between 2001 and 2008

\begin{tabular}{|l|c|r|r|r|r|}
\hline \multirow{3}{*}{ Watershed } & \multicolumn{5}{|c|}{ Site rating } \\
\cline { 2 - 6 } & Very good & Good & Fair & Poor & Very poor \\
\cline { 2 - 6 } & \multicolumn{5}{|c|}{$\%$} \\
\hline Big Boulder & 0 & 42 & 29 & 29 & 0 \\
\hline Clear & 0 & 40 & 60 & 0 & 0 \\
\hline Jim Ford & 0 & 25 & 25 & 38 & 12 \\
\hline Lake & 0 & 17 & 66 & 17 & 0 \\
\hline Myrtle & 0 & 56 & 44 & 0 & 0 \\
\hline Orofino & 0 & 0 & 75 & 25 & 12 \\
\hline Paradise & 0 & 0 & 50 & 38 & 0 \\
\hline Silver & 0 & 50 & 50 & 0 & \\
\hline
\end{tabular}


$0.3 \mathrm{~km}$ upstream from each of the 76 sampling sites during high precipitation months in 2008 and 2009. Soil erosion rates of $<2,2-5,5-15,15-25$ and $>25 \mathrm{mt} /$ $/ \mathrm{ha} / \mathrm{yr}$ were observed at $9,20,45,14$ and $12 \%$ of the sampling sites, respectively.

There was an excellent relationship between observed soil erosion rates and SMI water quality ratings (Tab. 3). Sites with an estimated erosion rate of less than $5 \mathrm{mt} / \mathrm{ha} / \mathrm{yr}$ were almost always adjacent to sampling sites with an SMI water quality rating of good $(p=0.02 *)^{1}$. Sites with erosion rates of less than $2 \mathrm{mt} / \mathrm{ha} / \mathrm{yr}$ and between 2 and $5 \mathrm{mt} / \mathrm{ha} / \mathrm{yr}$ had similar water quality ratings. Conversely, when soil erosion rates on land adjacent to sampling sites exceeded $5 \mathrm{mt} / \mathrm{ha} / \mathrm{yr} \mathrm{SMI}$ water quality scores were less than good $86 \%$ of the time $(\mathrm{p}=0.04 *)$. Land erosion rates of between 5 and $15 \mathrm{mt} / \mathrm{ha} / \mathrm{yr}$ were likely to result in water quality ratings of fair $(\mathrm{p}=0.02 *)$, while higher erosion rates of 15 to $25 \mathrm{mt} / \mathrm{ha} / \mathrm{yr}$ resulted in poor water quality $\left(\mathrm{p}=0.006^{* *}\right)$. When soil erosion rates exceeded $25 \mathrm{mt} / \mathrm{ha} / \mathrm{yr}$ SMI water quality scores in adjacent streams were often very poor $\left(p=0.05^{*}\right)$.

The study findings are significant and show a strong relationship between land use/management and local water quality within Idaho watersheds. Since sediments have been linked to a large portion of surface water degradation in the state, it is important that this study showed the direct relationship between soil erosion (sedimentation) and stream water quality. Simply put, within the eight studied watersheds, if land management practices are such that erosion is minimal

${ }^{1}$ Statistical significance level: $(*)$ if $\mathrm{p}<0.05$, $\left({ }^{* *}\right)$ if $\mathrm{p}<0.01,\left({ }^{* * *}\right)$ if $\mathrm{p}<0.001$.
$(<5 \mathrm{mt} / \mathrm{ha} / \mathrm{yr})$ it is likely that stream water quality will be good. Conversely, erosion levels exceeding $5 \mathrm{mt} / \mathrm{ha} / \mathrm{yr}$ are likely to impair adjacent water quality in streams.

The dominant land use adjacent to and up to $0.3 \mathrm{~km}$ upstream from each of the 76 sampling sites was related to the SMI water quality score (Tab. 4). The four dominant land uses identified in the eight studied watersheds included: forestry - no harvesting, forestry - harvesting, range and cropland (Tab. 1). Excellent relationships were found between the dominant land use and SMI water quality rating. As expected water quality was poorest adjacent to cropland $\left(\mathrm{p}=0.0001^{* * *}\right)$.

Water quality in streams adjacent to rangeland was generally good $\left(p=0.046^{*}\right)$;

TABLE 3. Relationship between visual erosion estimates made on land in 2007-2009 that was adjacent to the 76 benthic macro invertebrate sampling locations in eight Idaho watersheds

\begin{tabular}{|l|l|}
\hline $\begin{array}{l}\text { Soil erosion rate } \\
{[\mathrm{mt} / \mathrm{ha} / \mathrm{yr}]}\end{array}$ & $\begin{array}{l}\text { SMI water quality } \\
\text { rating }\end{array}$ \\
\hline$<2$ & good \\
\hline $2-5$ & good \\
\hline $5-15$ & fair \\
\hline $15-25$ & poor \\
\hline$>25$ & very poor \\
\hline
\end{tabular}

TABLE 4. Relationship between land use and water quality based on 76 sampling site locations in eight Idaho watersheds between 2007 and 2009

\begin{tabular}{|l|l|c|}
\hline $\begin{array}{l}\text { Dominant } \\
\text { land use }\end{array}$ & $\begin{array}{l}\text { SMI water } \\
\text { quality rating }\end{array}$ & Significance \\
\hline $\begin{array}{l}\text { Forestry } \\
\text { (no harvesting) }\end{array}$ & good & $0.0001^{* * *}$ \\
\hline $\begin{array}{l}\text { Forestry } \\
\text { (harvesting) }\end{array}$ & fair & $0.038^{*}$ \\
\hline Range & good & $0.046^{*}$ \\
\hline Cropland & poor & $0.0001^{* * *}$ \\
\hline
\end{tabular}


however, the intensity of grazing on these lands resulted in water quality ranging from good (minimal or no grazing) to poor (intensive grazing). Forest management practices influenced adjacent stream water quality (Tab. 4). Stream water quality was generally fair when the adjacent land had either recently been harvested (Clear-cut) or had experienced an uncontrolled burn in the last decade $\left(\mathrm{p}=0.03^{*}\right)$. Conversely, adjacent forestlands, which have received minimal, or no harvesting in the last 20 years had good water quality ratings $\left(\mathrm{p}=0.0001^{* * *}\right)$.

\section{CONCLUSIONS}

- Based on benthic macro invertebrate sampling, water quality ranged from good to very poor at 76 sampling sites in eight Idaho watersheds.

- Soil erosion rates of $<2,2-5,5-15$, $15-25$ and $>25 \mathrm{mt} / \mathrm{ha} / \mathrm{yr}$ were observed at $9,20,45,14$ and $12 \%$ of the 76 sampling sites, respectively.

- Strong, significant relationships were observed between SMI water quality ratings and observed soil erosion rates.

- Sites with soil erosion rates of $<5 \mathrm{mt} /$ /ha/yr generally had SMI water quality ratings of good. Conversely, when soil erosion rates on adjacent landscapes exceeded $5 \mathrm{mt} / \mathrm{ha} / \mathrm{yr}$ SMI water quality scores were less than good $86 \%$ of the time.

- A strong relationship between land use/management and adjacent water quality in the eight studied Idaho watersheds was observed.

- In general, the land use practices of forestry, range and agriculture adja- cent to streams resulted in SMI water quality ratings of good, good and poor, respectively.

\section{REFERENCES}

BARBOUR M.T., GERRITSEN J., GRIFFITH G.E., FRYDENBORG R,. MCCARRON R.E., WHITE J.S., BASTAIN M.L., 1996: A framework for biological criteria for Florida streams using benthic macroinvertebrates. J. North Amer. Benth. Soc. 15: 185-211.

CLARK W.H., MARET T.R., 1993: Protocols for assessment of biological integrity (Macroinvertebrates) for wade able Idaho streams. Water Quality Monitoring Report, Idaho Division of Environmental Quality, Boise, ID, USA.

GERRITSEN J., 1995: Additive biological indices for resource management. J. North Amer. Benth. Soc.. 14: 451-457.

HART D.D., 1994: Bridges: integrating basic and applied benthic science. J. North Amer. Benth. Soc. 13: 110-116.

HUELS J.P., 2002: A biological assessment incorporating benthic macro invertebrates of the Jim Ford Creek Watershed. M. S. thesis. University of Idaho, Moscow, ID USA.

KARR J.R., 1991: Biological integrity: a long neglected aspect of water resource management. Ecol. Appl. 1: 66-84.

PLAFKIN J.L., BARBOUR M.T., PORTER K.D., GROSS S.K., HUGHES R.M., 1989: Rapid bioassessment protocols for use in streams and rivers: benthic macro invertebrates and fish. EPA-440-4-89-001. U.S. EPA, Office of Water Regulation and Standards. Washington D.C.

REYNOLDSON T.B., NORRIS R.H., RESH V.H., DAY K.E., ROSENBERG D.M., 1997: The reference condition: a comparison of multimetric and multivariate approaches to assess water quality impairment using benthic macro invertebrates. J. North Amer. Benth. Soc. 16: 833-852.

TOSCH M., 2009: A biological assessment using benthic macro invertebrates as a water quality indicator for Clear Creek, Idaho County, Idaho. M. S. thesis. University of Idaho, Moscow, ID USA. 
Streszczenie: Ocena biologiczna cieków będacych pod niekorzystnym wplywem odptywu rumowiska ze zlewni w stanie Idaho, USA. Rumowisko rzeczne stanowi główne źródło zanieczyszczenia wód powierzchniowych w zlewniach Pacyfiku w północno-zachodnim regionie USA. W pracy przedstawiono wyniki badań prowadzonych w ośmiu zlewniach $\mathrm{w}$ celu określenia zależności między indeksem jakości wody SMI w 76 przekrojach kontrolnych a wartościami wskaźnika erozji gleb na przyległych obszarach. Jako wskaźnik jakości wody do określenia wartość SMI wykorzystano badania makro bezkręgowców wodnych, natomiast wskaźnik erozji gleb określano na podstawie obserwacji terenu w okresach maksymalnych opadów deszczu. Uzyskano silną zależność między wartościami SMI a wartościami wskaźnika erozji gleb. Stwierdzono, że gdy wskaźnik erozji gleb przekraczał wartość $5 \mathrm{mt} /$ ha/rok wówczas w $86 \%$ okresu obserwacji jakość wody była gorsza od dobrej, tj. słaba, zła lub bardzo zła. Zagospodarowanie terenu oraz działania w celu redukcji wartości wskaźnika erozji gleb poniżej $5 \mathrm{mt} / \mathrm{ha} /$ rok powinno poprawić jakość wody w ciekach.

\section{MS. received April 2010}

Author's address:

\section{Robert L. Mahler}

Professor of Soil and Environmental Sciences

University of Idaho

PO Box 442339

Moscow, Idaho, USA 83844-2339

bmahler@uidaho.edu 